\title{
Translating Culture in Postcolonial Arab/Anglophone Women's Narratives: The Case of Leila Aboulela's The Translator
}

\author{
Hasna KERSANI \\ Department of English, Faculty of Letters and Languages \\ University of Aboubekr Belkaid, Tlemcen, Algeria \\ Wassila HAMZA REGUIG MOURO \\ Department of English, Faculty of Letters and Languages \\ University of Aboubekr Belkaid, Tlemcen, Algeria
}

\begin{abstract}
Up to the twentieth century, the literature produced by Arab women writers consisted mainly of translations of the dominant Western literary works. The growing waves of intellectuals and writers in the Middle East, especially Egypt, lead to the evolution of Arabic literature as a whole. Coming from the Arab roots, living in Western Europe, and using the language of the ex-colonized, immigrant writers are set to be widely recognised is Western literary canons. Migration is a central theme in much of Arab/British or American literature. From Deleuze and Guattari's perspective, narratives produced by immigrant writers are said to be considered as minor literature, and they can also stand as a subcategory of it. Such a trend of writings is insignificant when compared to mainstream tradition (like English literature), and a subset of minor literature when other new dimensions are added to, if we may say, mainstream minor literature. This later might be the case of Arab/Muslim women-immigrant literature. The present research work attempts to investigate how critical immigrant women writers such as Leila Aboulela develop narratives where they offer new models of cross-cultural encounters. In so doing, such writings have acted as mediators and interpreters between variant cultures, and they have also forged new literary identities in the writers' adopted countries.
\end{abstract}

Keywords: Arab British literature, Arab immigrant women narratives, cultural translation, translational literature, postcolonial, Leila Aboulela, the Translator

Cite as: KERSANI, H., \& HAMZA REGUIG MOURO, W. (2020). Translating Culture in Postcolonial Arab/Anglophone Women's Narratives: The Case of Leila Aboulela's The Translator. Arab World English Journal for Translation \& Literary Studies 4 (1) 161-170. DOI: http://dx.doi.org/10.24093/awejtls/vol4no1.13 